\title{
Media Pembelajaran Matematika Pada Usia Dini Menggunakan Augmented Reality
}

\author{
Jaka Sutresna $^{\mathrm{a} 1}$, Fitri Yanti ${ }^{\mathrm{a} 2}$, Andin Eka Safitri ${ }^{\mathrm{a}}$ \\ ${ }^{a}$ Program Studi Teknik Informatika, Universitas Pamulang \\ Jl. Raya Puspitek, Buaran, Kec. Pamulang, Kota Tangerang Selatan - Banten \\ ${ }^{1}$ dosen00833@unpam.ac.id \\ dosen00848@unpam.ac.id \\ 3 dosen01122@unpam.ac.id
}

\begin{abstract}
Abstrak
Kurangnya minat belajar matematika pada anak-anak usia dini, Membuat pengajar kesulitan dalam menyampaikan materi matematika pada anak-anak usia dini. Rendahnya minat belajar matematika disebabkan oleh beberapa hal, salah satunya adalah cara guru menyampaikan materi pelajaran yang kurang menarik sehingga anak-anak bosan. Bagaimana memanfaatkan teknologi agar anak-usia dini tertarik belajar angka dan dan materi matematika. Yang akan dilakukan untuk menarik anak-anak dalam mempelajari angka dan materi matematika dalam proses belajar dengan teknologi Augmented Reality. Karena dengan Augmented Reality dapat menampilkan objek virtual ke dalam dunia nyata, Augmented Reality berjalan real time, adanya interaksi dengan benda 3 dimensi. Teknologi AR merupakan perkembangan perangkat mobile dengan fasilitas kamera bersolusi tinggi dan sensor-sensor yang mendukung. Maka semakin besar kemungkinan anak-anak usia dini paham pada materi yang disampaikan oleh pengajar. Belajar menggunakan media pembelajaran augmented reality tertentu akan lebih menarik anak-anak usia dini untuk minat dan memahami materi yang di sampaikan oleh para pengajar.
\end{abstract}

Kata kunci: Augmented_Reality, Matematika, Anak_Usia_Dini, Pembelajaran

\section{Mathematics Learning Media at Early Age Using Augmented Reality}

\begin{abstract}
Lack of interest in learning mathematics in early childhood makes it difficult for teachers to deliver mathematics material to early childhood. The low interest in learning mathematics is caused by several things, one of which is the way teachers deliver less interesting subject matter so that children get bored. How to use technology so that young children are interested in learning numbers and math materials. What will be done to attract children to learning numbers and math material in the learning process with Augmented Reality technology? Because Augmented Reality can display virtual objects in the real world, Augmented Reality runs real-time, there is interaction with 3-dimensional objects. AR technology is the development of mobile devices with high-resolution camera facilities and supporting sensors. So the more likely the early childhood children will understand the material presented by the teacher. Learning to use certain augmented reality learning media will attract young children to interest and understand the material conveyed by the teachers.
\end{abstract}

Keywords: Augmented_Reality, Matchematics, Childhood, Learning

\section{Pendahuluan}

Smartphone (telepon pintar) yang dapat digunakan dinamapun dan kapanpun telah tertanam teknologi yang dapat dimanfaatkan sebagai media pembelajaran. Dengan berkembangnya teknologi smartphone, Hardware dan software yang sebelumnya berjalan di PC sekarang dapat digunakan pada smartphone [1]. Yang sebelumnya pernah dikembangkan pada perangkat PC sekarang para pengembang aplikasi mengembangkan teknologi
Augmented Reality dengan memanfaatkan teknologi kamera yang ada di smartphone [1].

Augmented Reality, di sisi lain, mendefinisikan pengomposisian video dan grafik komputer secara realtime dengan penyelarasan perspektif yang benar - objek yang ditambah dapat dipilih secara bebas dengan menawarkan kontrol penuh atas hasil gambar [2].

Dalam proses belajar mengajar biasanya dengan metode konvensional dan buku panduan serta sejenisnya yang digunakan untuk media pembelajaran, dengan 
menerapkan teknologi Augmented Reality ini diproyeksikan sebagai inovasi dalam media pembelajaran agar pengguna mengerti dari materi yang disampaikan [3]. Dalam Pembelajaran dengan menggunakan teknologi Augmented Reality ini bersifat interaktif dan lebih menarik bagi pengguna karena informasi yang disampaikan lebih interaktif dibandingkan pembelajaran konvensional [3].

Perangkat untuk membantu yang digunakan guru Ketika mempermudah mengajar dan memahami materi yang disampaikan yang menggunakan media pembelajaran [4]. Media pendidikan sangat diperlukan sebagai perantara penyampaian materi meminimalkan kegagalan selama proses komunikasi berlangsung [5]. Dalam proses penyampaian pesan/materi tersebut ada kalanya berhasil ada kalanya tidak [5]. Sebagian anakanak usia dini mengeluhkan bahwa matematika adalah mata pelajaran yang sulit dipahami. Hal tersebut mengakibatkan kurangnya minat belajar matematika. Rendahnya minat belajar matematika disebabkan oleh beberapa hal, salah satunya adalah cara guru menyampaikan materi pelajaran yang kurang menarik sehingga anak-anak bosan.

Teknologi gabungan antara benda maya 2D atau 3D ke sebuah lingkungan nyata yaitu teknologi Augmented Reality [6]. Augmented Reality menyajikan interaksi yang menarik bagi pengguna karena pengguna dapat merasakan objek virtual seolah-olah ada dilingkungan pengguna melalui smartphone [7]. Matematika merupakan pengetahuan struktur yang terorganisasikan, aksiomaaksioma, sifat-sifat, seni atau matematika itu dapat disebut juga ilmu deduktif [8].

Mendeteksi penanda untuk menentukan lokasi dan orientasi kamera, dengan kamera, kemudian dikalibrasi ke sistem kemudian dapat menampilkan objek virtual di tempat yang telah ditentukan merupakan pekerjaan dari Pelacakan Berbasis Marker [9].

Pembuatan banyak konten 2D dan 3D dalam sebuah aplikasi terintegrasi yang merupakan software Blender. Blender menyediakan sekumpulan fitur dan kemampuan modeling, texturing, lighting, animation, dan video postprocessing [10].

Aplikasi Matematika menggunakan Augmented Reality dengan melibatkan guru dalam membuat prototype untuk siswa SD kelas 1-3. Jika siswa tidak melakukan pengukuran dengan benar (misalkan: dengan tumpang tindih kakinya, atau dengan meninggalkan jarak antara kakinya), maka aplikasi menunjukan masalah kepada siswa melalui hewan peliharaan virtual emotif. [11]

Berdasarkan masalah yang dipaparkan maka akan melakukan penelitian media pembelajaran matematika untuk usia dini menggunakan Augmented Reality.

\section{Metodologi Penelitian}

\section{A. Uraian Materi}

\section{1) Augmented Reality}

Teknologi AR merupakan salah satu yang sedang ramai dikembangkan dan diterapkan di smartphone yang mendukung AR. AR menyajikan interaksi yang menarik bagi kita karena kita dapat merasakan objek virtual seolah-olah ada dilingkungan kita melalui smartphone [7].

Ada 3 prinsip AR [12], yaitu :

a. AR dapat menampilkan objek virtual ke dalam dunia nyata,

b. AR berjalan secara interaktif dan real time,

c. Adanya interaksi dengan benda 3 dimensi.

Tampilan augmented dari lingkungan pengguna menyajikan antarmuka untuk operasi bergantung konteks, banyak di antaranya terkait dengan objek dalam tampilan dunia yang ditambah adalah antarmuka pengguna [13].

Vuforia Software Developent Kit (SDK) merupakan salah satu plugin yang mendukung pembuatan AR. Vuforia menyediakan fitur database target yang nanti dapat diunduh dan dapat diakses secara lokal aplikasi AR [7].

Unity $3 D$ atau biasa disebut Unity merupakan software yang digunakan untuk membuat berbagai macam game $2 D$ atau $3 D$. Unity memiliki kerangka kerja (framework) yang lengkap untuk pengembangan teknologi professional. Unity didukung beberapa bahasa pemrograman C\# dan javascript [7].

\section{2) Android}

Android memiliki market share $87 \%$ di dunia dan diperkirakan akan tetap bertahan pada massa yang akan datang. Popularitas android yang terus berkembang pesat inilah yang jadi alasan utama bahwa mengusai pemrograman android adalah langkah yang sangat bagus [14].

\section{3) $U M L$}

Unified Modelling Language (UML) merupakan bahasa yang digunakan untuk visualisasi serta sudah menjadi standar untuk digunakan dalam industry terutama yang berkaitan dengan alur atau proses, merancang dan membuat dokumentasi dari sebuah sistem perangkat lunak. [15].

$U M L$ merupakan sarana yang digunakan untuk memodelkan perancangan sistem yang berorientasi objek secara visual

\section{B. Metode}

Metode pengembangan Software berfungsi sebagai panduan apa saja yang harus dilakukan, bagaimana mendesain arsitektur sistem, dan tugas-tugas apa yang harus diselesaikan untuk membangun software atau aplikasi yang ingin dibuat [16]. Untuk metode pengembangan software dalam penelitian ini menggunakan model waterfall dan untuk step-by-step nya dapat dilihat dalam gambar dibawah ini

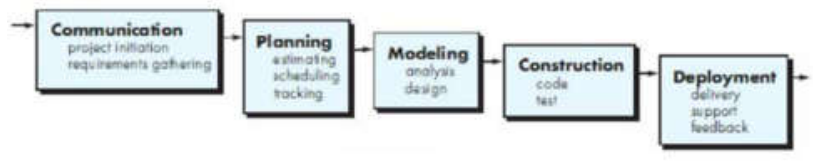

Gambar 1. Model Waterfall 
Metode pada penelitian ini mengaplikasikan augmented reality dalam memahami mata pelajaran matematika untuk anak usia dini. Beberapa tujuan pembelajaran untuk mempermudah memahami matematika dengan bantuan augmented reality, yaitu :

1. Siswa dapat menyebutkan angka-angka.

2. Siswa dapat mengoperasikan angka-angka

\section{HASIL DAN PEMBAHASAN}

\section{A. Arsitektur Sistem}

Untuk desain dari arsitektur sistem dapat dilihat pada gambar 1 berikut ini :

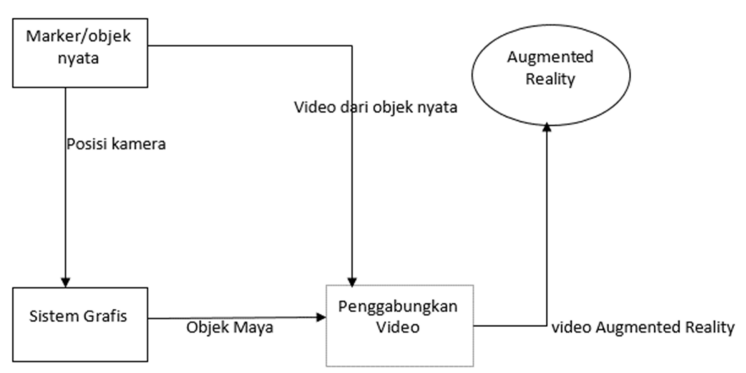

Gambar 2. Desain Arsitektur Sistem

\section{Cara Kerja AR:}

1. Marker untuk menampilkan objek 3 dimensi (3D) tertentu diarahkan ke kamera smartphone

2. Sistem grafis menerima dan mengubah objek marker tersebut ke objek maya

3. Menggabungkan objek animasi/video dari objek nyata dan dari objek maya

4. Maka terbentuklah animasi/video augmented reality

\section{B. Activity Diagram}

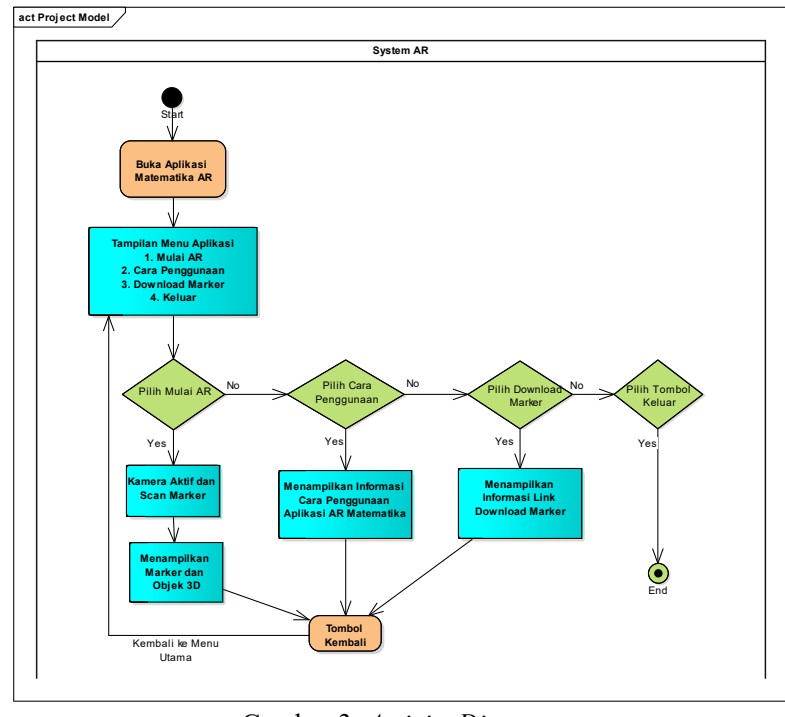

Gambar 3. Activity Diagram

C. Use Case Diagram

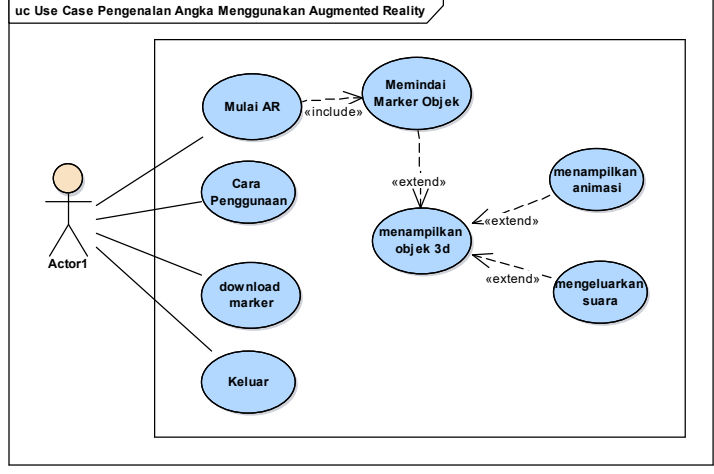

Gambar 4. Use Case Diagram

D. Actyvity Diagram

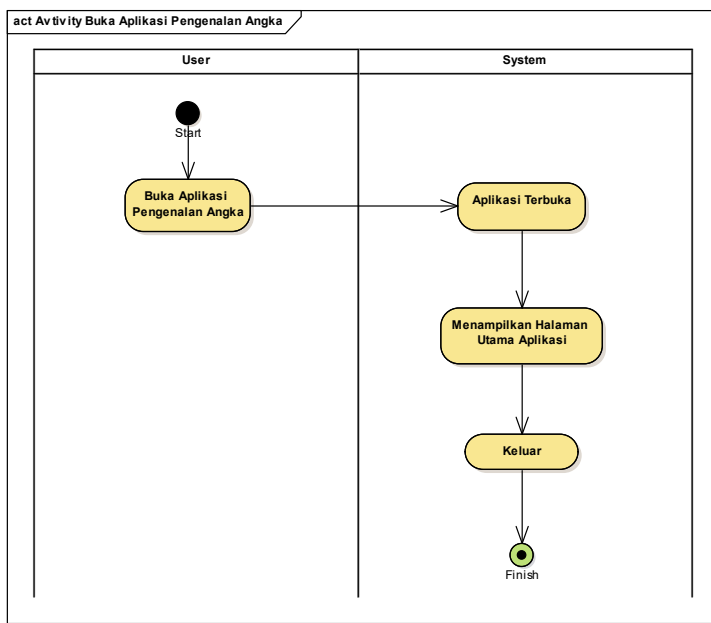

Gambar 5. Activity Proses membuka Aplikasi Pembelajaran Matematika

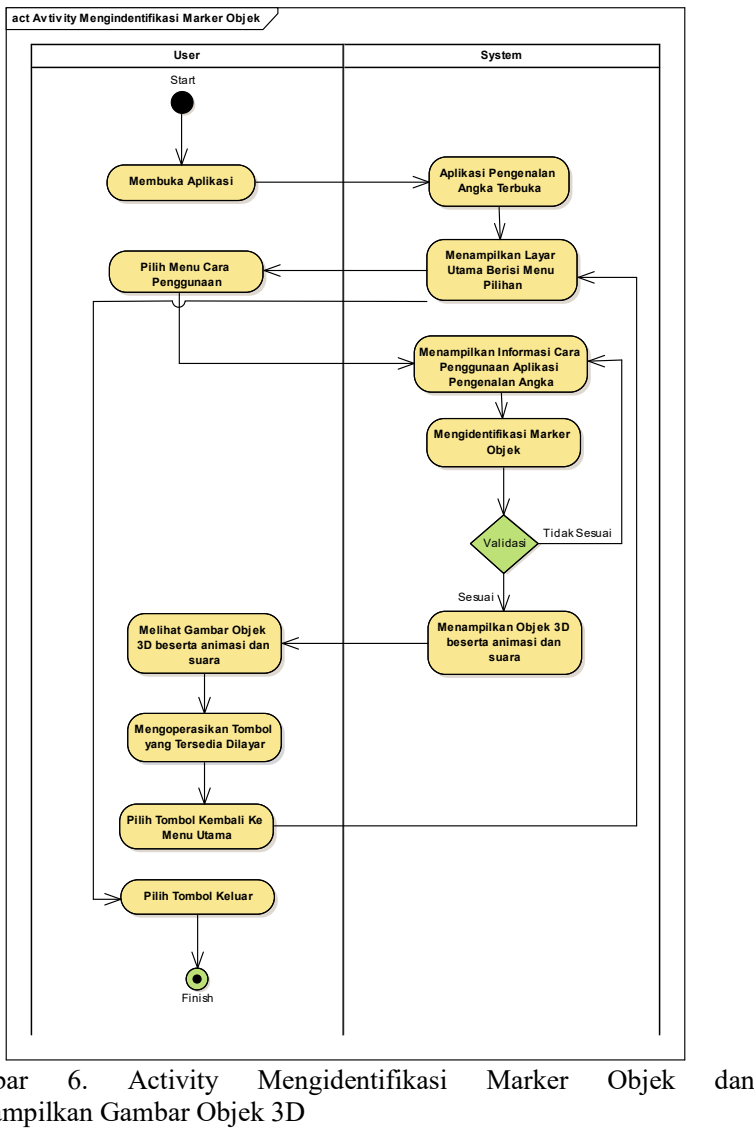




\section{E. Sequence Diagram}

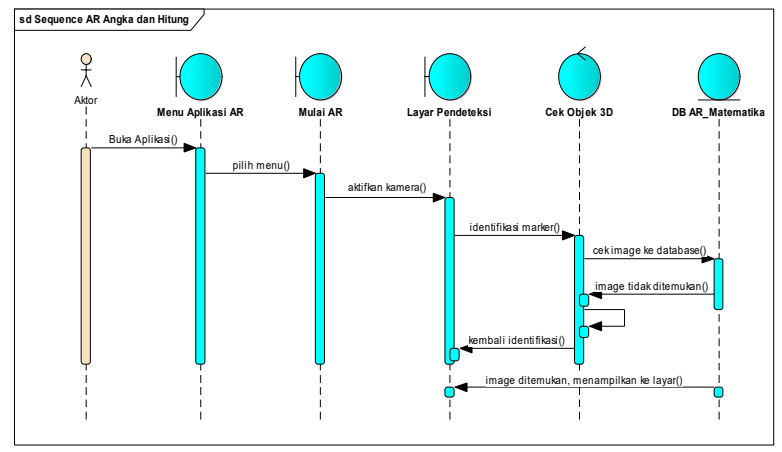

Gambar 7. Sequence Diagram

\section{F. Hasil Aplikasi}

Aplikasi yang dibangun adalah Agumented Reality Pengenalan Matematika yang diperuntukan untuk smartphone android. Untuk tahapan dalam membangun aplikasi ini adalah sebagai berikut :

Yang pertama dilakukan adalah pembuatan objek berupa marker gambar, objek marker gambar ini yang akan di pindai oleh aplikasi Augmented Reality Pengenalan Matematika menggunakna Augmented Reality. Didalam pembuatannya, tim peneliti dibantu menggunakan software photoshop.

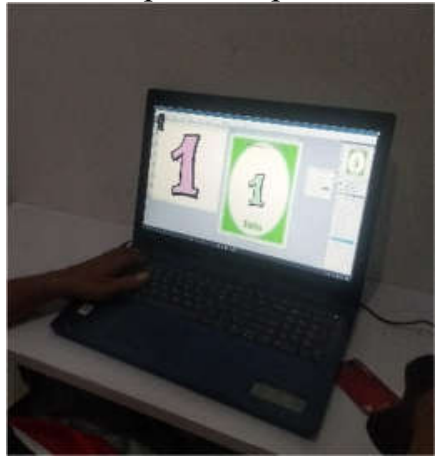

Gambar 8. Proses Pembuatan Objek Marker menggunakan Software Photoshop

Tahap selanjutnya adalah melakukan pembuatan Objek Gambar 3D yang dibantu oleh Software Blender. Objek Gambar 3D yang dibuat akan dipergunakan untuk menampilkan objek Gambar 3D berdasarkan model marker yang dipindai menggunakan Aplikasi Pengenalan Matematika menggunakna Augmented Reality.

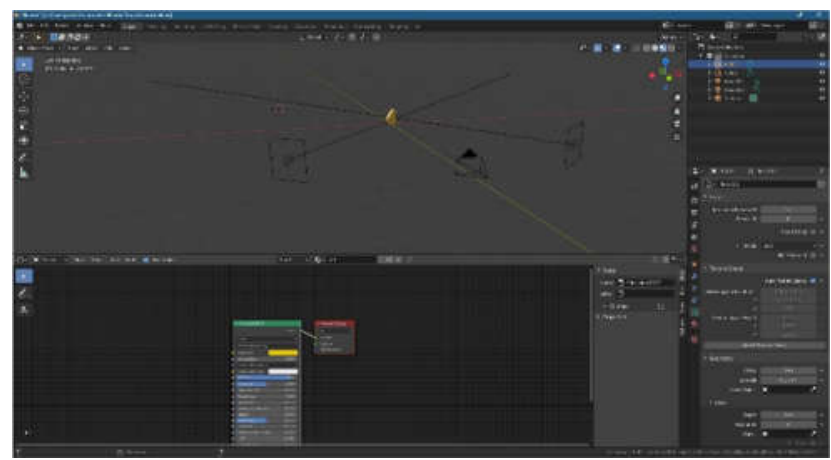

Gambar 9. Proses Pembuatan Objek Gambar 3D menggunakan Software Blender
Selanjutnya setelah Objek Marker Gambar terbentuk, maka dilakukan penyimpanan ke dalam database, untuk database yang digunakan di dalam Aplikasi Pengenalan Matematika menggunakan Augemented Reality ini adalah Vuforia,

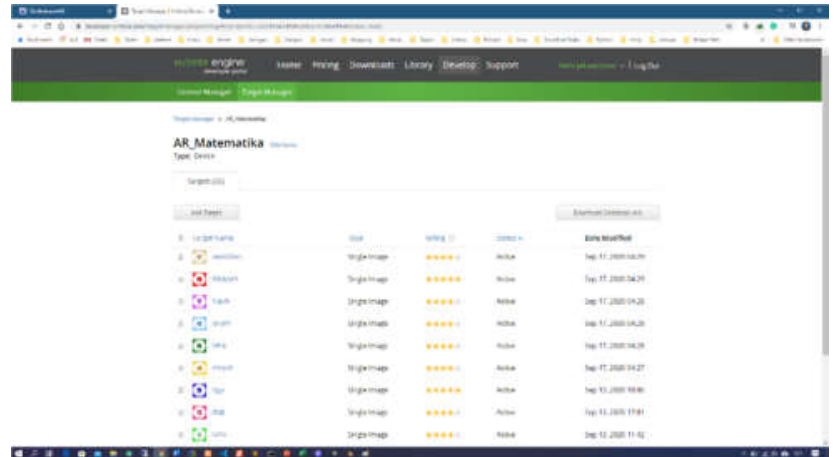

Gambar 10. Proses Upload Objek Marker ke Database Vuforia

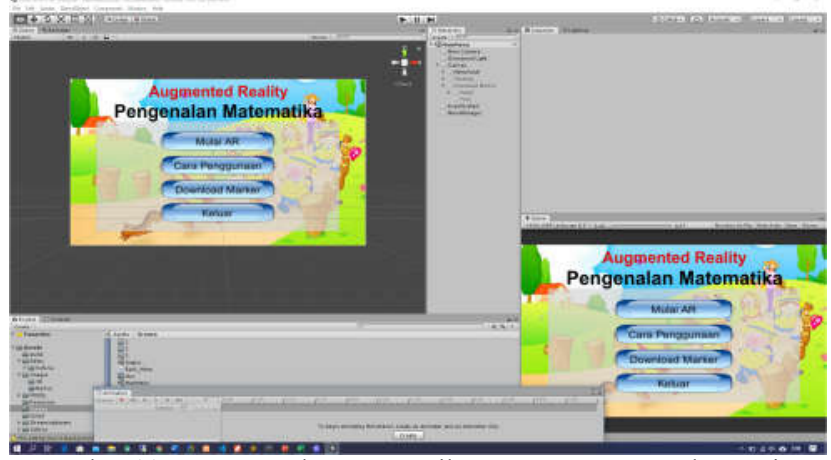

Gambar 11. Proses pembuatan tampilan utmana menggunakan Unity

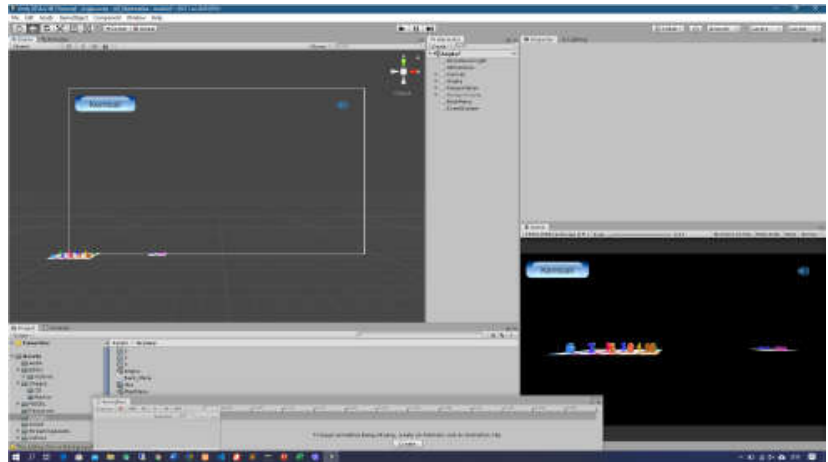

Gambar 12. Proses penggabungan objek marker dengan objek 3D

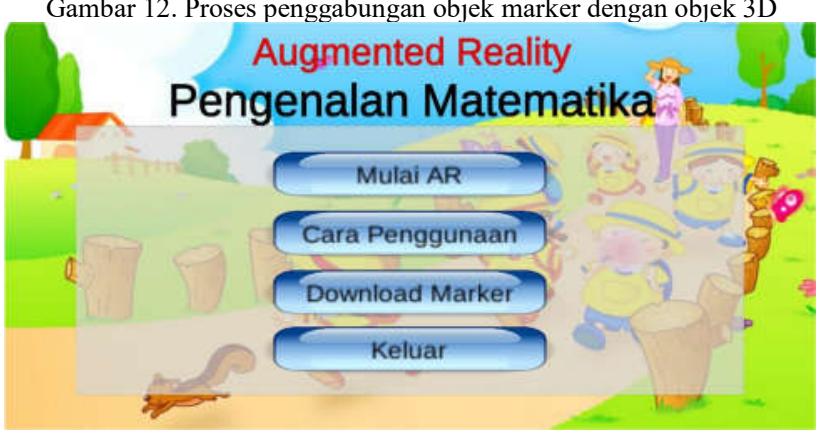

Gambar 13. Tampilan Menu Utama

Gambar 5 berisi menu-menu aplikasi yang terdiri dari : 1. Tombol Mulai AR, yaitu tombol yang fungsinya mengaktifkan dan memproses marker. 
2. Tombol menu cara penggunaan yang berisi informasi cara menggunakan aplikasi AR matematika.

3. Tombol menu download marker yang berisi informasi dan link untuk mendownload marker AR.

4. Tombol menu keluar untuk keluar dari aplikasi AR pengenalan matematika.

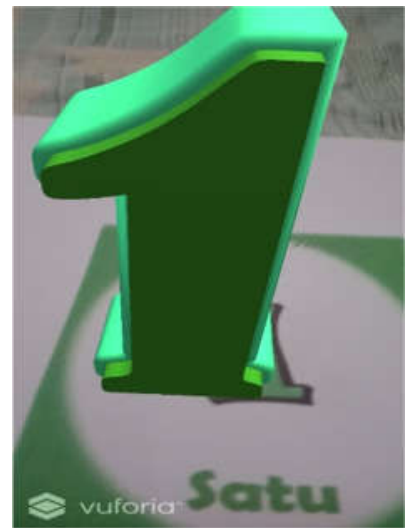

Gambar 14. Objek 3D Angka 1

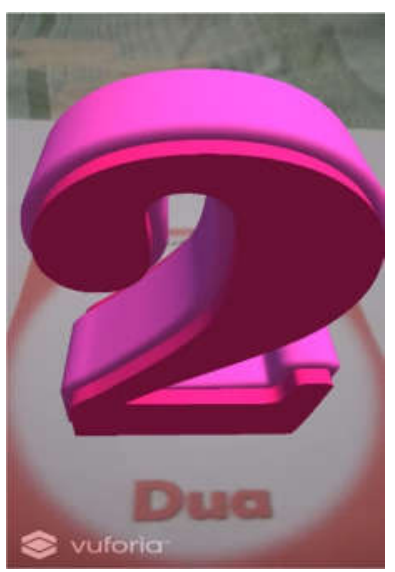

Gambar 15. Objek 3D Angka 2

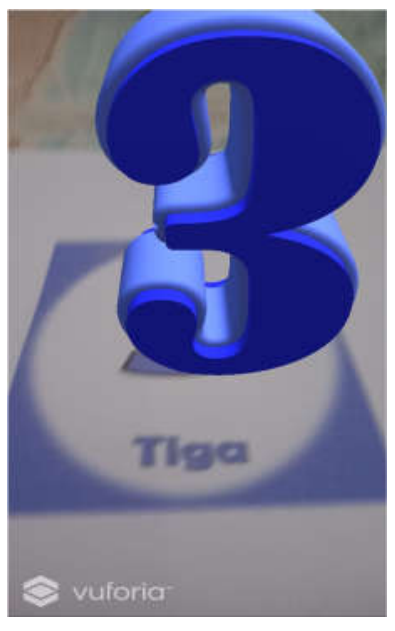

Gambar 16. Objek 3D Angka 3

Gambar 14, gambar 15, dan gambar 16 adalah tampilan angka yang ditampilkan dalam model 3 dimensi beserta audio dan ada juga animasi bergeraknya.

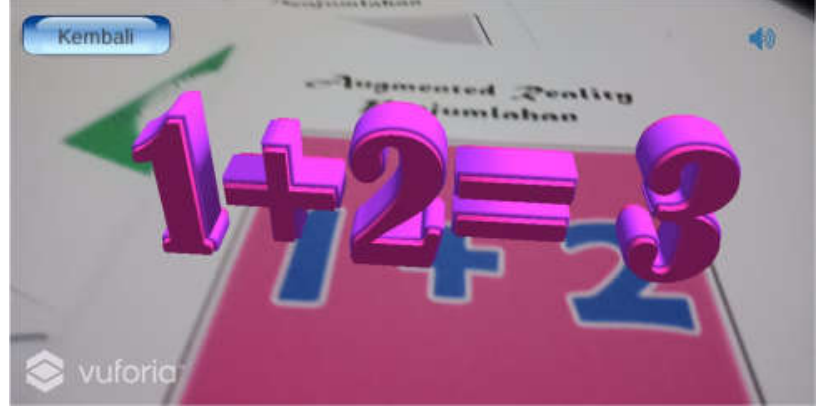

Gambar 17. Objek 3D Perhitungan

Gambar 17 adalah tampilan angka model 3 dimensi dan audio berupa penjumlahan beserta hasil dari perhitungannya.

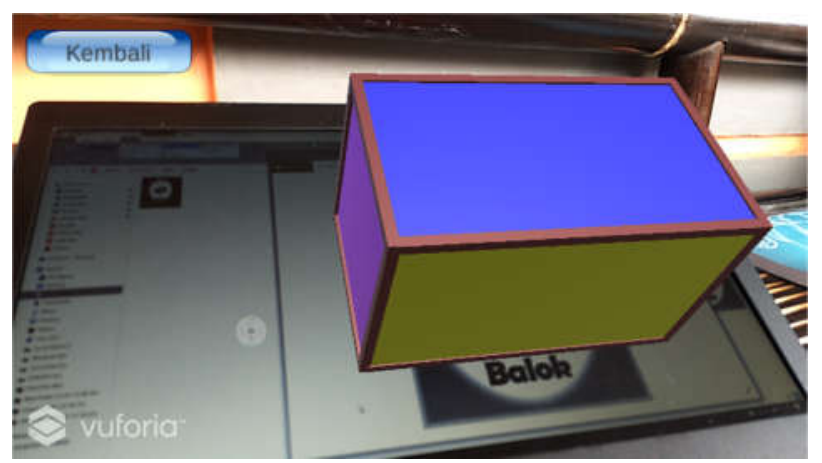

Gambar 18. Menmapilkan Objek 3D Bangun Ruang Balok

Gambar 18 adalah tampilan 3 dimensi model bangun ruang berupa balok.

\section{G. Pengujian}

Pengujian User Acceptance Test (UAT) yang dilakukan kepada 20 responden, kuisioner yang ditunjukan untuk anak usia dini dengan 5 pertanyaan.

TABEL I

PENGUJian USER ACCEPTANCE TEST (UAT)

\begin{tabular}{|c|c|c|c|c|}
\hline \multirow{2}{*}{ No } & \multirow{2}{*}{ Element Observasi } & \multicolumn{2}{|c|}{ Tanggapan } & \multirow{2}{*}{ Presentase } \\
\hline & & Ya & Tidak & \\
\hline 1. & $\begin{array}{l}\text { Menurut Anda, apakah } \\
\text { tampilan aplikasi } \\
\text { media pembelajaran } \\
\text { matematika } \\
\text { menggunakan AR ini } \\
\text { menarik? }\end{array}$ & 13 & 7 & $65 \%$ \\
\hline 2. & $\begin{array}{l}\text { Menurut Anda, apakah } \\
\text { penggunaan aplikasi } \\
\text { media pembelajaran } \\
\text { matematika AR ini } \\
\text { memberikan } \\
\text { kemudahan } \\
\text { interkatif? }\end{array}$ & 15 & 5 & $75 \%$ \\
\hline 3. & $\begin{array}{l}\text { Menurut Anda, apakah } \\
\text { aplikasi media } \\
\text { pembelajaran } \\
\text { matematika AR ini } \\
\text { mudah dioperasikan } \\
\text { atau digunakan? }\end{array}$ & 17 & 3 & $85 \%$ \\
\hline
\end{tabular}




\begin{tabular}{|l|l|c|c|c|}
\hline 4. & $\begin{array}{l}\text { Menurut Anda, apakah } \\
\text { informasi yang } \\
\text { ditampilkan sudah } \\
\text { cukup jelas? }\end{array}$ & 18 & 2 & $90 \%$ \\
\hline 5. & $\begin{array}{l}\text { Apakah Anda setuju } \\
\text { bahwa teknologi } \\
\text { Augmented Reality } \\
\text { yang ada dalam marker } \\
\text { ini menarik? }\end{array}$ & $40 \%$ \\
\hline
\end{tabular}

\section{KESIMPULAN}

Keberadaan Aplikasi Pembelajaran Matematika menggunakan Augmented Reality semakin memudahkan anak-anak usia dini dalam mempelajari matematika. Aplikasi Pembelajaran Matematika menggunakan Augmented Reality merupakan cara yang dapat menarik anak-anak usia dini untuk mempelajari matematika.

Untuk kedepannya semoga aplikasi pembelajaran matematika ini bisa dikembangkan dengan penambahan fiture berupa game matematika dan juga latihan.

\section{DAFTAR PUSTAKA}

[1] F. Z. Adami and C. Budihartanti, "PENERAPAN TEKNOLOGI AUGMENTED REALITY PADA MEDIA PEMBELAJARAN SISTEM PENCERNAAN BERBASIS ANDROID," JURNAL TEKNIK KOMPUTER AMIK BSI, vol. II, no. 1, pp. 122-131, 2016.

[2] T. D. Kammann, I. G. Olaizola and I. Barandiaran, "Interactive augmented reality in digital broadcasting environments," ReseachGate, vol. 2, pp. 881-887, 2006.

[3] O. D. E. Wulansari, T. Zaini and B. Bahri, "PENERAPAN TEKNOLOGI AUGMENTED REALITY PADA MEDIA PEMBELAJARAN," Jurnal Informatika, vol. 13, no. 1, pp. 169179,2013

[4] T. Yuliono, Sarwanto and P. Rintayati, "KEEFEKTIFAN MEDIA PEMELAJARAN AUGMENTED REALITY TERHADAP PENGUASAAN KONSEP SISTEM PENCERNAAN MANUSIA," Jurnal Pendidikan Dasar, vol. Vol.9 No.1, pp. 65-84, 2018.

[5] K. and M. , "Pengembangan Media Pembelajaran Berbasis Augmented Reality," Jurnal Edukasi Elektro, vol. Vol.1 No.1, 2017.

[6] I. D. G. W. Dhiyatmika, I. K. D. Putra and N. M. I. M. Mandenni, "Aplikasi Augmented Reality Magic Book Pengenalan Binatanguntuk Siswa TK," Lontar Komputer, vol. Vol. 6 No. 2, pp. 120-127, 2015.

[7] U. M. Arief, H. Wibawanto and A. L. Nastiti, Membuat Game Augmented Reality(AR) dengan Unity 3D, Yogyakarta: Andi, 2019.

[8] N. C. Siregar and M. , "PENGARUH PENDEKATAN DISCOVERY YANG MENEKANKAN ASPEK ANALOGI TERHADAP PRESTASI BELAJAR, KEMAMPUAN PENALARAN, KECERDASAN EMOSIONAL SPIRITUAL," JURNAL RISET PENDIDIKAN MATEMATIKA, vol. Vol.2 No. 2, pp. $224-234,2015$.

[9] S. Siltanen, Theory and applications of marker-based augmented reality, Finland: JULKAISIJA - UTGIVARE, 2012.

[10] N. D. Retnowati and S. Ermanto, "PERANCANGAN PESAWAT TERBANG DENGAN MENGGUNAKAN 3D BLENDER," ANGKASA, vol. Vol. 5 No.2, pp. 123-132, 2013.

[11] I. Radu, "Discovering educational augmented reality math applications by prototyping with elementary-school teachers," in IEEE, 2016.
[12] R. Azuma, Y. Bailot, R. Behringer, S. Feiner, S. Julier and B. MacIntyre, "Recent Advances in Augmented Reality," IEEE Computer Graphics and Applications, pp. 34-47, 2001.

[13] T. Holleler, S. Feiner, D. Hallaway, B. Bell, M. Lanzagorta, D. Brown, S. Julier, Y. Baillot and L. Resenblum, "User interface management techniques for collaborative mobile augmented reality," Computers \& Graphics, vol. 25, pp. 799-810, 2001.

[14] N. Safaat H, android pemrograman Aplikasi mobile Berbasis android, bandung: informatika bandung, 2018.

[15] S. Dharwiyanti and R. S. Wahono, Pengantar Unified Modeling Language (UML), Jakarta: IlmuKomputer.Com, 2003.

[16] R. S. Pressman, Software Engineering A Practitioner's Approach, New York, NY, USA: McGraw-Hill, 2009. 